\title{
Improving the quality of education in Russian language and literature lessons
}

\section{Dilshoda NABIYEVA ${ }^{1}$}

Shahrisabz branch of Tashkent State Pedagogical University named after Nizami

\begin{tabular}{l} 
ARTICLE INFO \\
\hline Article history: \\
Received April 2021 \\
Received in revised form \\
20 April 2021 \\
Accepted 15 May 2021 \\
Available online \\
25 June 2021 \\
\hline
\end{tabular}

ABSTRACT

This article explores the problems that arise in the educational process and its solutions, ways to improve the quality of education, the requirements for the teacher in modern education.

2181-1415/C 2021 in Science LLC.

This is an open access article under the Attribution 4.0 International (CC BY 4.0) license (https://creativecommons.org/licenses/by/4.0/deed.ru)

\footnotetext{
Keywords:

modern education, quality of knowledge, psychological problems, group technologies, modern approach to education, oral methods.
}

\section{Rus tili va adabiyoti darslarida ta'lim sifatini oshirish}

\author{
Kalit so'zlar: \\ zamonaviy ta'lim, \\ bilim sifati, \\ psixologik muammolar, \\ guruh texnologiyalari, \\ ta'limga zamonaviy \\ yondoshish, \\ og'zaki usullar.
}

\section{ANNOTATSIYA}

Ushbu maqolada o'quv jarayonida yuzaga keladigan muammolar va uning yechimlari, ta'lim sifatini oshirish yo'llari, zamonaviy ta'lim jarayonida o'qituvchiga qo'yiladigan talablar ko'rib chiqilgan.

\footnotetext{
${ }^{1}$ Lecturer, Shahrisabz branch of Tashkent State Pedagogical University named after Nizami. Shahrisabz, Uzbekistan.
} 


\section{Повышение качества обучения на уроках русского языка и литературы}

\author{
Ключевые слова: \\ современное образование, \\ качество знаний, \\ психологические \\ проблемы, \\ групповые технологии, \\ современный подход к \\ обучению, \\ устные методы.
}

\begin{abstract}
АННОТАЦИЯ
В статье исследуются проблемы, возникающие в образовательном процессе и пути их решения, пути повышения качества обучения, требования к учителю в современном образовании.
\end{abstract}

The quality of education is one of the main problems of modern educational institutions.

Kipling wrote, "Education is the greatest blessing in the world, if it is of the highest quality. Otherwise, it's completely useless" [12].

Today, the main goal of education is not only the accumulation of a certain amount of knowledge, skills, and abilities by students, but also the preparation of the student as an independent subject of educational activity. At the heart of modern education is the activity of both the teacher and, no less important, the student. It is this goal - the upbringing of a creative, active personality who knows how to learn, improve independently, and the main tasks of modern education are subordinate. After all, as Bernard Shaw said: "The only path leading to knowledge is activity".

"All children by nature have a predisposition, a desire for knowledge, all of them can be taught", Y.A. Komensky insisted in a number of sections of his "Great Didactics". Comenius attached decisive importance in the prevention of academic failure to the correct formulation of the process of teaching and upbringing. The problem of children's academic failure and how to prevent it has long worried teachers.

Today we are dealing with an avalanche-like growth of schoolchildren's academic failure.

UNSUFFICIENCY - a lag in learning, in which the student does not master the knowledge provided by the curriculum at a satisfactory level in the allotted time.

Contrary to popular belief, poor performance in schoolchildren is not always explained by low mental abilities or unwillingness to learn.

The failure of schoolchildren is naturally associated with their individual characteristics and with the conditions in which their development proceeds.

There are two groups of main reasons for the existing gaps in learners' knowledge:

1) internal, subjective, emanating mainly from the student himself;

2) external, objective, mostly independent of the student.

One of the most common internal reasons for academic failure is insufficient development of thinking and other cognitive processes in schoolchildren, the unpreparedness of these children for intense intellectual work in the learning process (mental retardation from their peers). These children are excitable, easily injured. They get tired quickly. Therefore, it is necessary to create such a microclimate in the classroom so that both they and their comrades do not feel a big difference in their mental development, to exclude any humiliation and contempt for them. 
Another subjective reason due to which some of our students do not have time is the low level of skills in the educational work of schoolchildren (inattention in the classroom, lack of understanding until the end of the material presented). Misunderstandings are mainly due to knowledge gaps.

In this case, you can suggest the following:

Paired dialogues (check theoretical knowledge) at the beginning of the lesson,

Collective lesson in alternating pairs: The goal is to bypass as many of your comrades as possible, and they, in turn, prepare questions at home.

Group work. When practicing practical skills on a topic, mixed groups are created. The work is carried out by the method of discussion.

The identification of the reasons for academic failure is due to the need to find the right ways to overcome this problem.

In order to improve the quality of students' knowledge, the following should be used in the classroom:

- High quality preparation for the lesson.

- Psychological approach to the lesson, the learning process.

- Knowledge quality control.

- Teacher's personality, his authority

New educational technologies and their individual elements, which are actively used in Russian language and literature classes, as well as in extracurricular activities, will help to successfully solve this problem.

Active use of the following educational technologies leads to the solution of these problems:

- group technologies (pair, group work);

- problem-solving lessons;

- differentiated educational technologies;

- integration technology;

- Technology of game methods;

Couple collaboration is an ideal form for collaboration and mutual support. In a pair, students can check each other out, reinforce new material, and review past.

The following types of assignments are used in oral work:

1. Peer review of the rule (oral questioning). Tells the student next to the rule, gives examples, explains them. Then the students switch roles, evaluate each other. The teacher can ask any couple.

2. The same task is slightly modified: one student asks a question on the material studied, the other answers. Their conversation is heard on the board. Educational communication attracts attention, encourages intervention.

3. The following form of oral work is also used with homework: one asks, the other answers. The questions can be very different: find two words for the unstressed vowel at the root in homework, identify the topic and main idea, find the grammatical basis of the sentence, give examples of coordination, control, subordination. This work is useful for checking complex homework.

4. In a pair of written assignments, students prefer this form of work to a dictionary dictation form for their peers. At home, students create a dictation that lacks the spelling on a separate card with the instruction "Compiled ..." according to the spelling rules learned. After exchanging cards in class and completing the assignment, they will receive 
a "Done ..." signature below. Making cards develops vigilance, responsibility in spelling and punctuation, helps to expand the vocabulary of schoolchildren, teaches them to work with textbooks, reference books.

Quality of knowledge is an integral set that characterizes the results of students' learning activities: completeness, depth, efficiency, flexibility, specificity, generalization, systematicity, awareness, strength. This is something that requires constant work and improvement to keep pace with the times.

The components of the quality of education are:

- quality of education of schoolchildren in the areas of education;

- the quality of the formation of general educational skills of schoolchildren (textbook, work with the text, the ability to plan, analyze, draw conclusions, etc.);

- quality of education of schoolchildren (controlled by special methods);

- quality of personality development of school students (emotional, will, cognitive interest, motivation, etc.);

- quality of social adaptation (ability to find a specific "place" in society).

Primary education is a special stage of a child's development. For the first time, educational activity becomes leadership. But an elementary school student is also a kid who loves to play. How to structure your work so that the children in the class are interested, at the same time, they learn to think, work with learning materials, as they acquire new knowledge.

To do this, the teacher must structure the work as follows:

- adherence to traditions and introduction of innovations;

- professional development;

- mastering and introduction of the latest information technologies;

In this case, the teacher identifies the common problems of schoolchildren and the reasons for their correction;

- reveals the level of formation of the system of quality of students' knowledge;

- records the individual achievements of schoolchildren by creating a portfolio;

- Organizes project activities to develop students' creative abilities.

In education, the teacher is always given a special role, because he is the main driving force of quality education, and he must have certain characteristics, for example:

- have modern educational technologies;

- ability to make learning material comprehensible;

- creative use of teaching methods;

- ability to organize a children's team;

- interest in children;

- Brightness of speech, politeness, relevance to life, ability to work outside the classroom.

It is necessary to master modern educational technologies and methods in modern conditions.

To provide a clear teaching experience, I effectively use the simplest software available that every teacher can use - a Power Point. The presentation allows the teacher to independently compose the educational material based on the characteristics of a particular class, topic, subject, which allows you to build a lesson in such a way as to achieve the maximum educational effect. 
The use of presentations at each stage of the Russian language and literature lessons is optional. I turn to the possibilities of ICT when the effectiveness and expediency of such work is obvious and gives a result. For example, when studying the topic "Morphemic and word-formation parsing of a word" I used a presentation in which a problematic question was posed to the children by a fictional character. In the 6th grade, I still consider the elements of the game acceptable. (Slide 3.4). This type of work makes the children interested, so when studying some topics, I invite stronger students to create their own presentation:

- in literature lessons, about the life and work of poets and writers, about the historical events underlying the work, etc.

- in the lessons of the Russian language, these are presentations about linguists, clusters on the learned spelling rules, etc.

Such activity fosters interest in the lesson, makes it more interesting.

Also, in literature lessons, I practice watching fragments of feature films based on the studied works. In my opinion, this encourages students with low motivation to learn to start reading the work.

In literature lessons, when talking about a particular writer, it is important for me that the students see him as a person, and not a soulless portrait. For example, when studying the biography of A.S. Pushkin in the 6th grade, It needs to pay great attention to the topic "Lyceum in the life of Pushkin". The presentation allows you to immerse the children in the atmosphere of that time. (Slide 5.6.7). So, when studying Yesenin's work, we say that he did not hide his hooligan past when he scandalized. But this was only a temporary period of his life, which did not overshadow him the main thing - the most holy - of the Motherland, Russia, pure faith. And when studying the biography of N.V. Gogol in the 7th grade, the guys independently found interesting facts from the biography of the writer. This work made it possible to create a situation of success for low-performing students.

An important component of the quality of education is the personality of the teacher, his authority. qualities.

The teacher is the main driving force of quality education, he must have certain

Anton Semenovich Makarenko in his book "Pedagogical Poem" wrote: "The teacher must like the student, be sure to achieve this! How? Watch yourself? Sure. But the main thing is that the teacher should be the authority of KNOWLEDGE" [11].

I think every teacher should strive to achieve this goal. To achieve emotional contact with students.

Also, in the work of a teacher, control over the quality of knowledge, analysis of the results of this control is very important. Without evaluating the student's work, no assimilation process is possible. It has a great influence on students, on their attitude to the subject, teacher, school and the world around them in general. Therefore, the teacher must make serious demands on the process of assessing the quality of students' knowledge. The teacher needs to create a situation of success in the classroom, which is one of the ways to improve the quality of education. But nevertheless, the estimate should be real, in no way overestimated.

Now education is increasingly launching a mechanism that ensures a balance between personal and personal needs and self-development (self-development, selfeducation) aims to create such technologies and methods of influencing the individual through, ensuring an understanding of the individual's identity and readiness to change society. 
Although there is a lot of talk now about individualizing and stratifying education, the teacher often forgets that two classrooms are not the same. Each class team has its own characteristics, focus, and behavioral characteristics. All of these should be taken into account when choosing assignments for both high school and high school students.

\section{REFERENCES:}

1. Resolution of the President of the Republic of Uzbekistan "On additional measures to further improve the education system" Presidential decree-4884 06.11.2020.

2. Resolution of the President of the Republic of Uzbekistan "On measures to support research activities in the field of public education and the introduction of a system of continuous professional development" Presidential decree-4963 25.01.2021.

3. Resolution of the President of the Republic of Uzbekistan "On measures to radically increase the effectiveness of out-of-school education in the public education system" Presidential decree-4467 30.09.2019.

4. Ильичев А.В., Петровский В.С., Яковлев А.И. и др Внедрение информационных технологий в предметной и надпредметной деятельности / Под ред. А.В. Ильичева. - М.: Просвещение, 1995. - С. 240.

5. Кулагина И.Ю. Возрастная психология: Развитие ребенка от рождения до 17 лет: Учеб. пособие / И.Ю. Кулагина; Ун-т Рос. акад. образования. - 4-е изд. М.: УРAO, 1998.

6. Образовательная программа Муниципального общеобразовательного учреждения «Средняя общеобразовательная школа №27».

7. Тикунова А.И., В.П. Канакина. Сборник диктантов и творческих работ. // М., «Просвещение», 1992.

8. Электронные образовательные ресурсы нового поколения: в вопросах и ответах. - М.: Агентство «Социальный проект», 2007.

9. Яковлев А.И. Информационно - коммуникационные технологии в образовании - М.: Просвещение, 2003.

10. Яковлев А.И. Информационно-коммуникационные технологии в дистанционном обучении: Доклад на круглом столе «ИКТ в дистанционном образовании». - М.: МИА, 1999.

11. https://kopilkaurokov.ru/russkiyYazik/prochee/sposoby_povyshieniia_kachie stva_obrazovaniia_na_urokakh_russkogho_iazyka_i_litie.

12. https://urok.1sept.ru/articles/682949. 